\title{
Pemetaan Obyek Wisata Di Kabupaten Lebak Menggunakan Gis (Geografi Informasi Sistem)
}

\author{
Diana Triwardhani ${ }^{1}$, Ati Zaidiah ${ }^{2}$ \\ ${ }^{1}$ Ekonomi dan Bisnis Fakultas Ekonomi, ${ }^{2}$ Sistem Informasi Fakultas Ilmu Komputer \\ Universitas Pembangunan Nasional Veteran Jakarta \\ Jalan RS Fatmawati No. 1, Pondok Labu, Jakarta Selatan, DKI Jakarta 12450 \\ 1'diana.wardhani@upnvj.ac.id, ${ }^{2}$ zaidiah@gmail.com
}

\begin{abstract}
Abstrak - GIS diperuntukan memetakan suatu obyek wisata yang ada di kabupaten Lebak hal ini di perlukan agar masysrakat yang ingin berkunjung ke obyek wisata Lebak dapat dengan mudah mengakses informasi tentang obyek wisata tersebut, sehingga membantu memberikan informasi mengenai beberadaan obyek wisata yang terdapat di kabupaten Lebak. Dengan demikian dapat dimanfaatkan oleh masyarakat untuk lebih mengetahui obyek wisata apa yang hendak dikunjungi, dan dalam konteks pemakainnya sistem yang di buat berbasiskan web (Web Based), sehingga dapat di akses kapanpun dan dimana pun.
\end{abstract}

Kata kunci : Web, obyek wisata

\section{PENDAHULUAN}

Provinsi Banten khususnya Lebak merupakan propinsi yang berjarak kurang lebih sekitar 104 km dari ibu kota Jakarta, sangat di kenal karena memiliki daerah wisata yang menarik pada setiap kabupaten bahkan sampai kecamatan yang ada di Provinsi Banten ini. Seperti salah satu obyek wisata daerah Baduy dan yang lainnya yang ada di daerah Lebak yang mungkin belum terinformasikan.

Kebanyakan Wisatawan tidak mengetahui letak dari objek wisata yang ada pada daerah-daerah yang akan dikunungi secara geografis, kabupaten Lebak yang mempunyai luas 304.472 hektar (BPS.Kab Lebak, 2018). Padahal obyek wisata di derah lebak ini sangat banyak.Untuk mengetahui objek wisata yang ada wisatwan masih banyak yang menggunakan peta.Dengan menggunakan peta, pengguna dapat mengetahui letak objek wisata tersebut bukan hanya namanya saja, tetapi daerah-daerah sekitar bahkan kecamatan dan kabupaten dapat diketahui melalui peta yang ditampilkan.Dengan menggunakan peta, setiap objek wisata dapat dicantumkan berdasarkan kabupaten ataupun kecamatan.Tahun 2015 pemerintah kabupaten Lebak mencatat sebanyak 50.271 wisatawan yang berkunjung ke kabupaten Lebak.Berbagai jenis wisata seperti wisata pantai, wisata alam, budaya, agrowisata maupun wisata sejarah yang dapat dijumpai dengan mudah.Akan tetapi dalam penyampaian informasinya masih manual, seperti pemberian brosur, pamflet, poster, dan buku-buku dilakukan jika ada wisatawan yang datang berkunjung ke suatu objek wisata yang dikunjunginya.

Informasi yang dibuat oleh Dinas Pariwisata setempat menjadi sangat terbatas karena masyarakat luas tidak dapat mendapatkan informasi tentang kepariwisataan sehingga perlu dibuatkan media alternatif untuk menginformasikan pariwisata di kabupaten Lebak agar dapat dinikmati masyarakat luas yaitu dengan melalui fasilitas internet.

Oleh karena informasi yang disampaikan pada masyarakat mengenai sebuah wilayah memang masih jarang diterapkan, apalagi yang berbasis komputer. Walaupun ada, kebanyakan yang ditemui adalah sebuah sistem pemetaan yang berdiri sendiri (stand alone desktop programming). Kurangnya informasi mengenai keberadaan obyek wisata di kabupaten Lebak ini merupakan salah satu latar belakang mengapa topik ini dipilih. Kegunaan sistem seperti ini dapat menambah pengetahuan bagi masyarakat daerah sekitar mengenai informasi yang di berikan. Namun dengan banyaknya informasi penyajian pun harus disesuaikan dengan objeknya.Untuk itu dibutuhkan 
informasi yang tepat dan akurat untuk menyebarluaskan informasi tersebut.Penyebaran informasi geografis ini dapat berupa data spasial (wilayah) maupun data non spasial berupa informasi yang berhubungan dengan keberadaan wilayah. Penyebaran informasi pada bidang geografis juga bermanfaat di bidang objek wisata alam yang menggunakan informasi pemetaan (geografis) untuk menyebarkan secara rinci dimana setiap kota maupun daerah itu mempunyai objek wisata yang dapat dikunjungi oleh para wisatawan. Untuk itu diperlukan sistem informasi yang dapat menyajikan informasi objek wisata di kabupaten Lebak.

Oleh karena itu, peneliti mencoba untuk membuat sebuah sistem pemetaan tentang keberadaan obyek wisata di kabupaten Lebak, dengan berbasiskan web sehingga tingkat pemakaiannya (usability) dapat lebih luas, karena keberadaan sebuah informasi yang realtime, cepat dan akurat menjadi hal yang penting saat ini bagi masyarakat. Data yang diperlukan harus dapat diakses dengan efektif dan efisien oleh pengguna.

Dengan aplikasi GIS (Geographic Information System atau system informasi geografi) maka hal tersebut dapat dilakukan. GIS merupakan suatu alat yang dapat digunakan untuk mengelola (input, manajemen, dan output) data spasial atau data yang bereferensi geografis.Setiap data yang merujuk lokasi di permukaan bumi dapat disebut sebagai data spasial bereferensi geografis.

Penggunaan Sistem Informasi Geografis (SIG) ini sudah sangat popular, dimulai dengan tujuan membuat peta digital, dengan cepat menjadi alat yang sangat berharga dalam proses pengambilan keputusan untuk berbagai industri. GIS telah diterima secara luas, semakin banyak aplikasi yang ditemukan di hampir semua disiplin ilmu, termasuk: pertanian, bisnis, teknik, transportasi, ilmu lingkungan, perawatan kesehatan, hukum, parawisata, dan real estate,(Mohammad A. Rob ,2003, Mezyad Alterkawi, 2001, Moh Muthohir, Ahmad Zainudin, 2016, Verka JOVANOVI, Angelina NJEGUŠ 2008, I Gede Riana, Ni Luh Putu Wiagustini, 2014)

Namun penggunaan GIS yang diperuntukan memetakan suatu obyek wisata yang ada di kabupaten Lebak sepengetahuan peneliti belum ada, sehingga hal ini di perlukan agar masysrakat yang ingin berkunjung ke obyek wisata Lebak dapat dengan mudah mengakses informasi tentang obyek wisata tersebut, sehingga membantu memberikan informasi mengenai beberadaan obyek wisata yang terdapat di kabupaten Lebak. Hal ini bermanfaat bagi masyarakat untuk lebih mengetahui obyek wisata apa yang hendak dikunjungi, dan dalam konteks pemakainnya sistem yang di buat berbasiskan web (Web Based), sehingga dapat di akses kapanpun dan dimana pun. Hal ini dimaksudkan agar masyarakat yang ingin memanfaatkannya dapat dengan mudah untuk pengaksesanya.

\subsection{Tujuan Penelitian}

Membuat web yang berisi obyek-obyek wisata yang berada di kabupaten Lebak.

\subsection{Kegunaan Penelitian}

Memberikan informasi kepada masyarakat dalam hal pencarian tentang obyek-obyek wisata yang berada di kabupaten Lebak.

\section{Tinjauan Pustaka}

Pengertian Sistem Informasi Geografis (SIG) adalah sebuah sistem komputer yang memiliki kemampuan untuk mengambil, menyimpan, menganalisa, dan menampilkan informasi dengan referensi geografis (Budianto. 2010.)

Menurut sumber Esri (1990), bahwa sistem informasi geografis adalah kumpulan terorganisasi dari perangkat keras komputer, perangkat lunak, data geografi dan personil yang dirancang secara efisien untuk memperoleh, menyimpan, mengupdate, memanipulasi, menganalisis, dan menampilkan semua bentuk informasi yang bereferensi geografis (Prahasta, Eddy. 2006) 


\subsection{Definisi Sistem Informasi Geografis}

Definisi Sistem Informasi Geografis adalah suatu sistem untuk mendayagunakan dan menghasil gunakan pengolahan dan analisis data spasial (keruangan) serta data non- spasial (tabular), dalam memperoleh berbagai informasi yang berkaitan dengan aspek keruangan, baik yang berorientasi ilmiah, komersil, pengelolaan maupun kebijaksanaan. Berikut adalah beberapa keuntungan penggunaan SIG (Hanafi. 2011)

1. SIG mempunyai kemampuan untuk memilih dan mencari detail yang diinginkan, menggabungkan satu kumpulan data dengan kumpulan data lainnya, melakukan perbaikan data dengan lebih cepat dan memodelkan data serta menganalisis suatu keputusan.

2. SIG dengan mudah menghasilkan peta-peta tematik yang dapat digunakan untuk menampilan informasiinformasi tertentu. Peta-peta tematik tersebut dapat dibuat dari peta-peta yang sudah ada sebelumnya, hanya dengan memanipulasi atribut-atributnya.

3. SIG memiliki kemampuan untuk menguraikan unsur-unsur yang terdapat di permukaan bumi menjadi beberapa layer data spasial, dengan layer permukaan bumi dapat direkonstruksi kembali.

\section{Komponen Utama Sistem Informasi Geografis (SIG)}

1. Daya Manusia

Komponen manusia memegang peranan yang sangat menentukan, karena tanpa manusia maka sistem tersebut tidak dapat diaplikasikan dengan baik.Jadi manusia menjadi komponen yang mengendalikan suatu sistem sehingga menghasilkan suatu analisa yang dibutuhkan.

\section{Software}

Software merupakan sistem modul yang berfungsi untuk mengoperasikan sistem informasi geografis.Sebuah software SIG harus menyediakan fungsi dan tool yang mampu melakukan penyimpanan data analisis dan menampilkan informasi geografis. Dengan demikian elemen yang harus terdapat dalam komponen software SIG adalah tools untuk melakukan input dan transformasi data geografis, sistem manajemen basis data, tools yang mendukung query geografis, analisis dan visualisasi, Geographical User Interface (GUI) untuk memudahkan akses pada tools geografi.

\section{Hardware}

Sistem informasi geografis memerlukan spesifikasi komponen hardware yang sedikit lebih tinggi dibanding spesifikasi komponen sistem informasi lainnya. Hal ini disebabkan karena data-data yang digunakan dalam SIG, penyimpanannya membutuhkan ruang yang besar dan dalam proses analisanya membutuhkan memory yang besar dan processor yang cepat. Beberapa hardware yang sering digunakan dalam sistem informasi geografis adalah personal komputer, mouse, digitizer, printer, plotter dan scanner.

4. Aplikasi sistem informasi geografis dalam proces perencanaan

Sistem informasi geografis sudah diaplikasikan dalam berbagai bidang seperti pertanian, lingkungan manajemen sumber daya alam, parawisata, geologi, perencanaan, dan lain sebagainya.keunggulan sistem informasi geografis sehingga digunakan pada bidang-bidang tersebut adalah karena kemampuannya mengintegrasikan antara data spasial dan data atribut sehingga dalam analisisnya mampu menghasilkan informasi yang kompleks.

5. Data

Hal yang merupakan komponen penting dalam sistem informasi geografis adalah data.Secara fundamental sistem informasi geografis bekerja dengan dua tipe data yaitu data vektor dan data raster.Setiap data yang merujuk lokasi di permukaan bumi dapat disebut sebagai data spasial bereferensi geografis. Misalnya data kepadatan penduduk suatu daerah, data jaringan jalan suatu kota, data distribusi lokasi pengambilan sampel, dan sebagainya. Data SIG dapat dibagi menjadi dua macam, yaitu data grafis dan data atribut atau tabular.Data grafis adalah data yang menggambarkan bentuk atau kenampakan objek di permukaan bumi, sedangkan data tabular adalah data deskriptif yang menyatakan nilai dari data grafis tersebut (Pahlevy. 2010.) 
Telah dijelaskan diawal bahwa SIG adalah suatu kesatuan membentuk sistem yang terdiri dari berbagai komponen, tidak hanya perangkat keras komputer beserta dengan perangkat lunaknya saja, akan tetapi harus tersedia data geografis yang benar dan sumberdaya manusia untuk melaksanakan perannya dalam memformulasikan dan menganalisa persoalan yang menentukan keberhasilan SIG.

\section{Sub-Sistem SIG}

Suatu sistem informasi geografis menyediakan empat perangkat kemampuan untuk menangani data tereferensi secara geografi dan dijelaskan dengan gambar seperti pada gambar 2.1 di bawah ini (Prahasta. 2006):

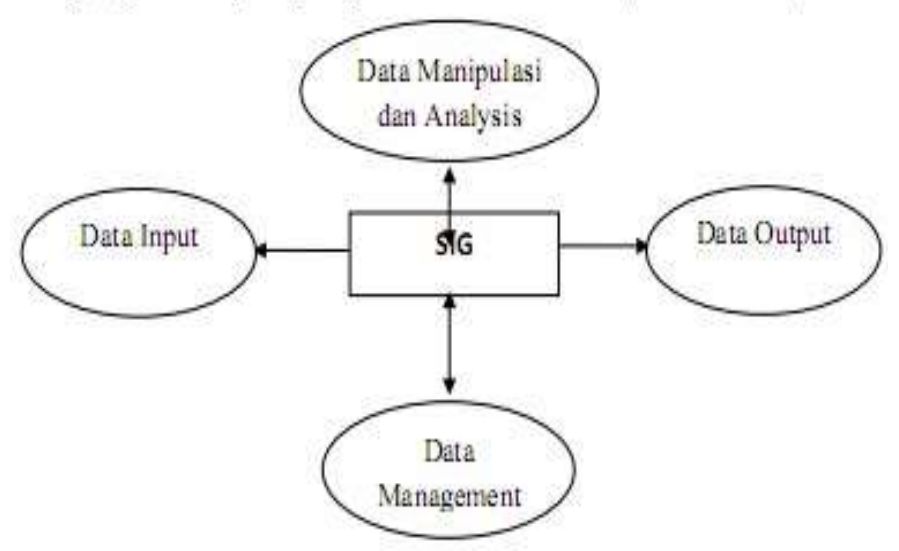

\section{Gambar 1 Sub-Sistem SIG}

1) Data Input

Sub-sistem ini bertugas untuk mengumpulkan dan mempersiapkan data spasial dan attribut dari berbagai sumber. Bertanggung jawab dalam mengkonversi atau mentransformasikan format-format data aslinya ke dalam format yang dapat digunakan oleh SIG dalam format digital. Data tersebut mungkin dapat direkam (capture) baik dalam bentuk vektor maupun raster. Cara ini dapat dilakukan melalui pendigitalan manual, scanning, atau dari data digital yang ada.

\section{2) Data Output}

Sub-sistem ini menampilkan atau menghasilkan keluaran seluruh atau sebagian basis data baik dalam bentuk softcopy (on-screen or electronic file) atau hardcopy (paper or film). Dalam mempertimbangkan suatu SIG perlu untuk mengkaji kualitas, akurasi, dan mudah dalam penggunaannya dalam menghasilkan output yang diinginkan. Umumnya sistem berbasiskan vektor dapat menghasilkan peta yang berkualitas lebih tinggi dari pada sistem berbasiskan raster.

3) Data Management

Sub-sistem ini mengorganisasikan baik data spasial maupun atribut ke dalam sebuah basis data sedemikian rupa sehingga mudah dipanggil, diupdate dan diedit. Ada fungsi-fungsi yang dibentuk oleh SIG untuk menyimpan dan menerima data dari basis data, kemampuan ini sama seperti halnya dengan kemampuan yang disediakan oleh perangkat lunak manajemen basis data. Data dimasukan ke dalam struktur data yang sudah didefinisikan yang mungkin saling berhubungan atau mungkin juga tidak saling berhubungan.

4) Data Manipulasi dan Analisis

Sub-sistem ini menentukan informasi yang dapat dihasilkan oleh SIG. SIG melakukan manipulasi dan pemodelan data untuk menghasilkan informasi yang diharapkan. Fungsi analisis SIG secara umum dibagi kedalam dua bagian yaitu analisis spasial dan analisis non-spasial. Analisis spasial memerlukan pengetahuan hubungan geografi antara data- data (points, lines, and polygons) yang terdapat dalam SIG. sedangkan analisis non-spasial menggambarkan suatu query dari database, sejenis fungsi dalam database management software. 


\section{Metode Penelitian}

Sesuai dengan tujuan yang telah ditetapkan maka penelitian ini menggunakan analisis deskriftif kualitatif dan analisis kuantitatif. Analisis kualitatif dilakukan dengan melakukan Tanya jawab dengan informan terkait obyekobyek wisata yang ada di daerah kabupaten Lebak.

\section{Prosedur Penelitian}

Penelitian ini adalah penelitian untuk memetakan obyek wisata di kabupaten Lebak. Kegiatan yang akan dilakukan terdiri dari beberapa tahap yaitu tahap survey, tahap pelaksanaan. Adapun perincian dari kedua fase tersebut akan diuraikan sebagai berikut.

1) Tahapan Survey

Peninjauan lokasi pada onyek-obyek wisata yang ada di kabupaten Lebak dan identifikasi kebutuhan sistem untuk pemetaan lokasinya..

2) Tahapan Pelaksanaan

Pelaksanaan kegiatan penelitian ini diantaranya yaitu dengan pembuatan Web GIS Obyek Wisata yang ada di Kabupaten Lebak, pelatihan admin pengelolaan web.

Tahapan ini meliputi :

1) Koordinasi dengan Mitra dan Persiapan Desain GIS

Pada tahapan ini, tim peneliti melakukan koordinasi dengan dinas pariwisata Kabupaten Lebak guna memperoleh data yang diperlukan dan menentukan spesifikan produk web GIS yang diinginkan.

2) Merancang GIS

Setelah Tim Peneliti memperoleh data tentang obyek wisata di kabupaten Lebak dan spesifikasi produk Web GIS yang akan dikembangkan, maka tahapan selanjutnya adalah membangun GIS.

a. Flowchart System

Berikut ini bagan alir GIS obyek wisata kabupaten Lebak, seperti Gambar 1.

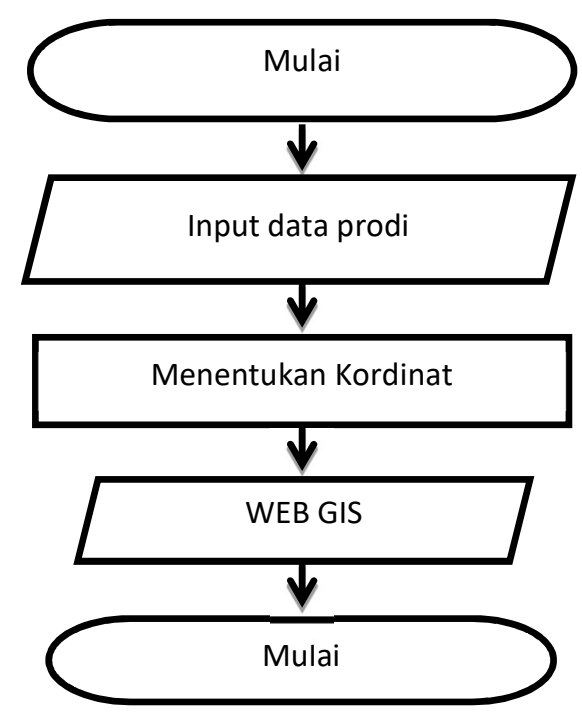

Gambar 1. Bagan alir GIS obyek wisata kabupaten Lebak 


\section{b. Diagram Konteks}

Context diagram merupakan aliran yang memodelkan hubungan antara sistem dengan entitas, yang direpresentasikan dengan lingkaran tunggal yang mewakili keseluruhan sistem. Aliran dalam context diagram memodelkan masukan ke sistem dan keluaran dari sistem. Adapun diagram konteks GIS obyek wisata kabupaten Lebak seperti Gambar 2.

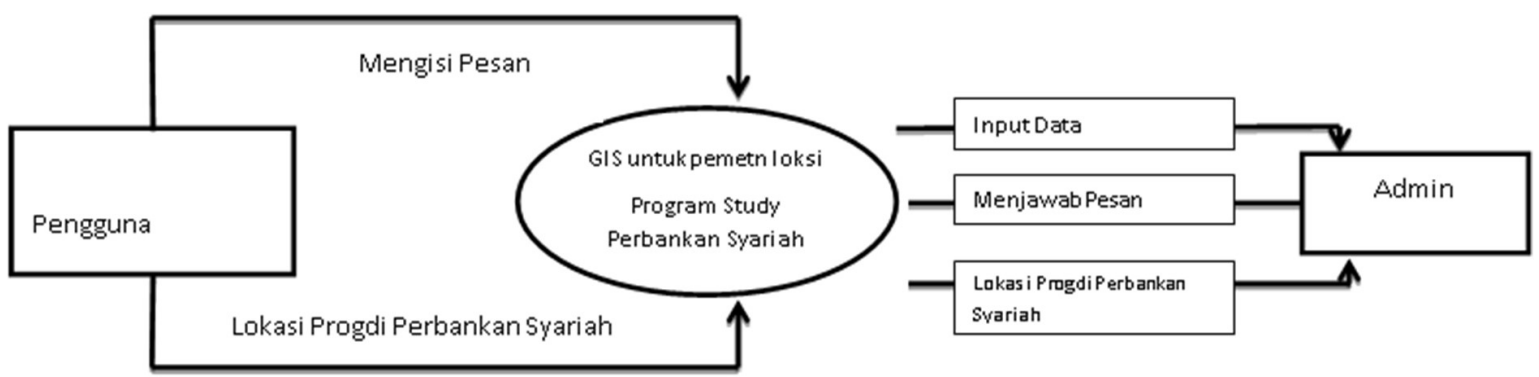

Gambar 2. GIS untuk pemetaan Lokasi

\section{HASIL DAN PEMBAHASAN}

Pada tahap awal dilakukan kunjungan kepada obyek wisata yang ada di kabupaten Lebak yaitu : Musium Multatuli, Arung Jeram Ciberang, Ranca Lentah dan Alun-Alun.

Setelah data terkumpul maka dimulai proses pembuatan GIS nya :

1. Website yang akan dibuat ini rencana akan dinamai yaitu http//wisata-lebak.info.com yang berisi informasi mengenai obyek wisata di kabupaten Lebak. Mengingat biasanya setiap website obyek wisata jarang menampilkan informasi detail tentang obyek wisata yang terangkum secara bersamaan. Dengan karya ilmiah ini berinisiatif mengumpulkan informasi tersebut.

2. Kemudian berikutnya akan di bahas mengenai cara input data tentang obyek wisatanya. Struktur Website http//wisata-lebak.infoperbankansyariahjakarta.com

Website http//wisata-lebak.info.com terdiri dari dua bagian halaman yang terintegrasi, di antaranya:

1. Halaman User Guest/ Frontend (Pengunjung)

2. Halaman User Administrator/ Backend (CMS)

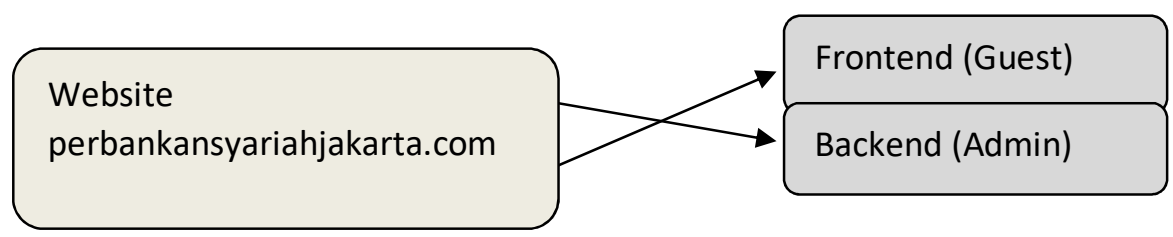

Selanjutnya akan diberikan panduan kepada user admin dalam mengatur dan mengelola proses input, edit dan delete list obyek wisata yang akan di database.

\section{Frontend}

Merupakan halaman informasi pengunjung

Websit wisata-lebak.info.com yang berisi informasi lokasi. Kami menggunakan fasilitas google maps untuk menampilkan informasi alamat ini. Selain itu didukung dengan informasi profil 


\section{Backend}

Merupakan halaman user administrator website wisata-lebak.info yang berisi pengaturan fitur-fitur untuk pengaturan dan pengelolaan fitur-fitur informasi pada isi halaman user guest. Pada bagian backend ini anda dapat menambah, edit dan delete list perguruan tinggi yang sudah dikumpulkan.

\section{Petunjuk Penggunaan Website}

\subsection{Frontend}

Pada bagian frontend ini di bagi ke dalam tiga bagian besar gambar. Berikut ini adalah detailnya.

\section{Bagian I}

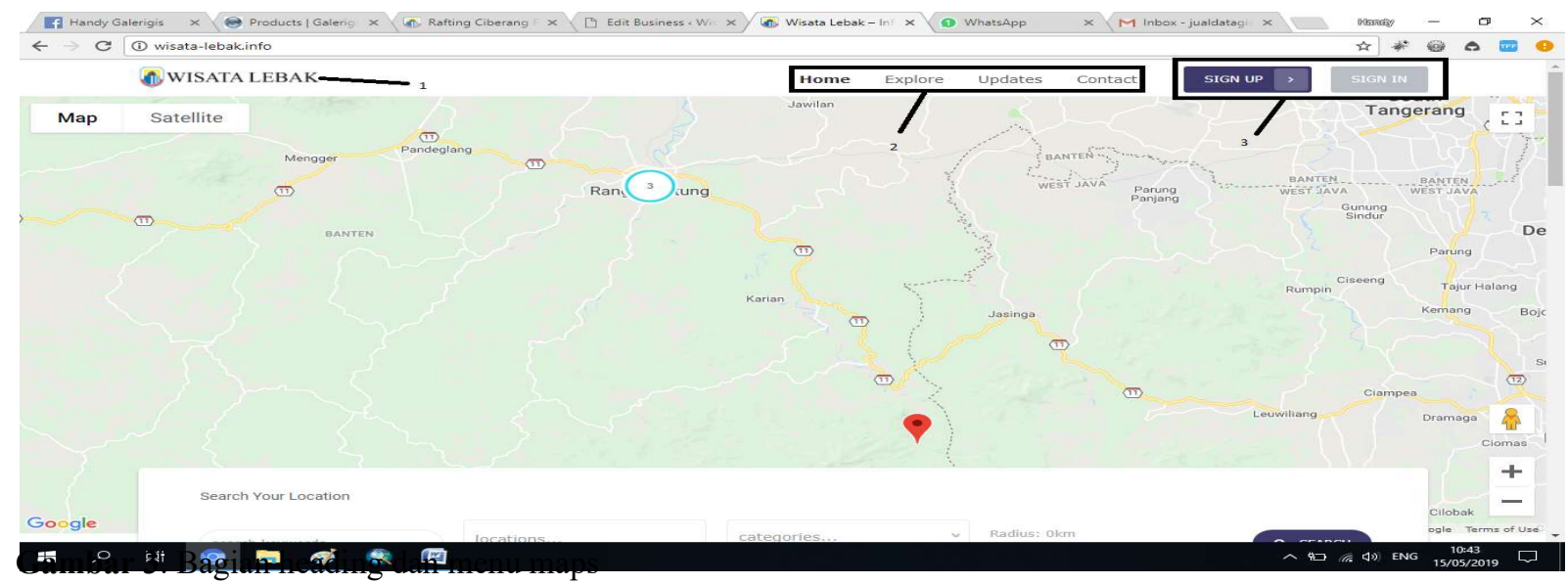

Keterangan:

1. Logo atau judul website. Pada gambar no 1 dapat di isikan tulisan/judul website atau alternatif dapat di masukkan logo website.Di sini memasukkan gambar logo.

2. Menu Header. Berisikan menu-menu yang memandu dari website.

3. Menu Login. Pengunjung dapat mendaftar untuk juga berpartisipasi memasukkan list tentang pariwisata yang ada di kabupaten Lebak.. Bagian ini dapat dihapus oleh bagian "system admin" (ada di dokumentasi system admin)

4. Google maps. Berisikan list-list tempat parawisata yang di tampilkan dalam bentuk peta. Dalam hal ini memanfaatkan fasilitas dari google maps.Silahkan di" zoom in" dengan menekan tombol plus yang ada di kanan bawah. Jika sudah keluar ikonnya maka akan keluar informasi tempat wisata di lokasi tersebut,jika di klik. Lebih jauh, dapat dilihat detail informasi dengan mengklik "view details". Ambil salah satu contoh saja adalah rafting ciberang Rangkasbitung. 


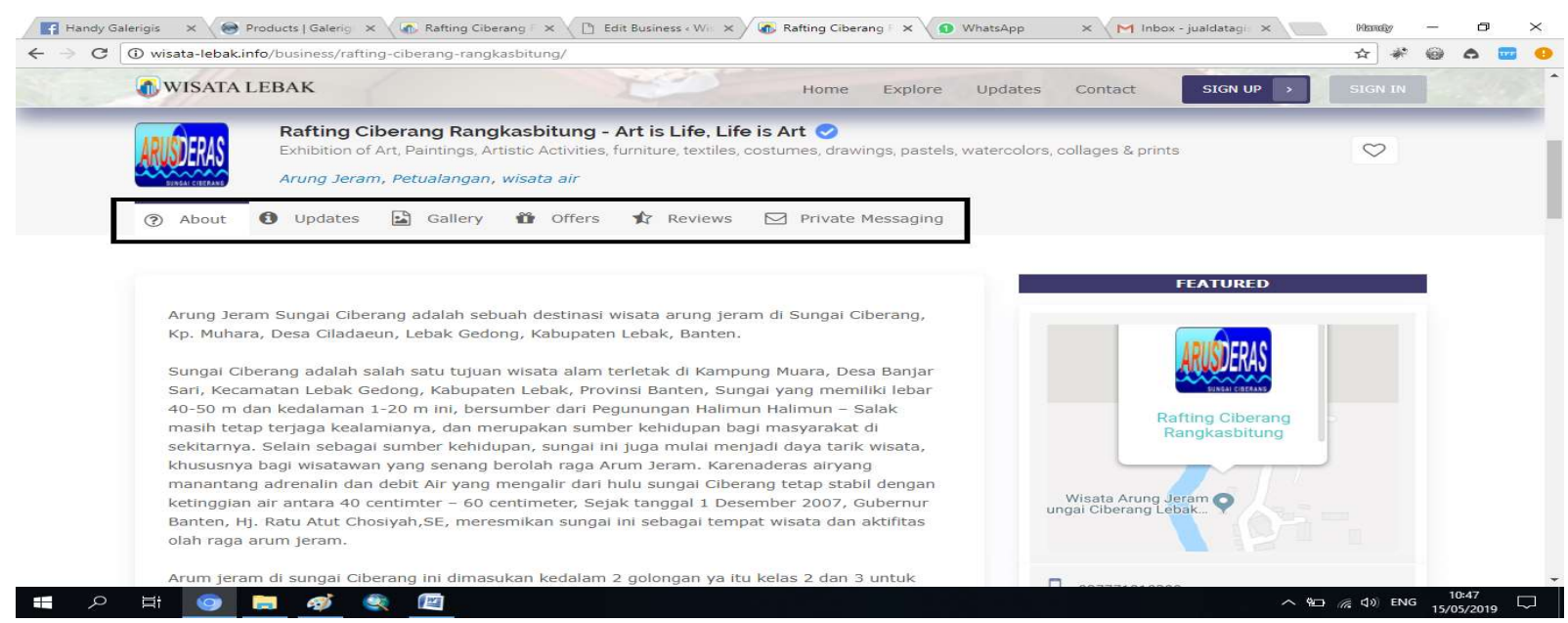

Gambar 4. Detail informasi tempat wisata.

Ada beberapa tab yang ada di bagian ini, yaitu :

1. Updates. Ini seperti update status seperti facebook.

2. Gallery. Kumpulan gambar-gambar yang terkais dengan wisata

3. About. Berisikan tentang profil dan informasi tambahan mengenai tempat wisata.

4. Private Message.

5. Rating. User /umum dapat memberikan rating dari tempat wisata ini. User lain harus mendaftar terlebih dahulu jika mau memberikan rating

6. Offer. Informasi tambahan mengenai tempat wisata (jika ada)

\section{Bagian II}

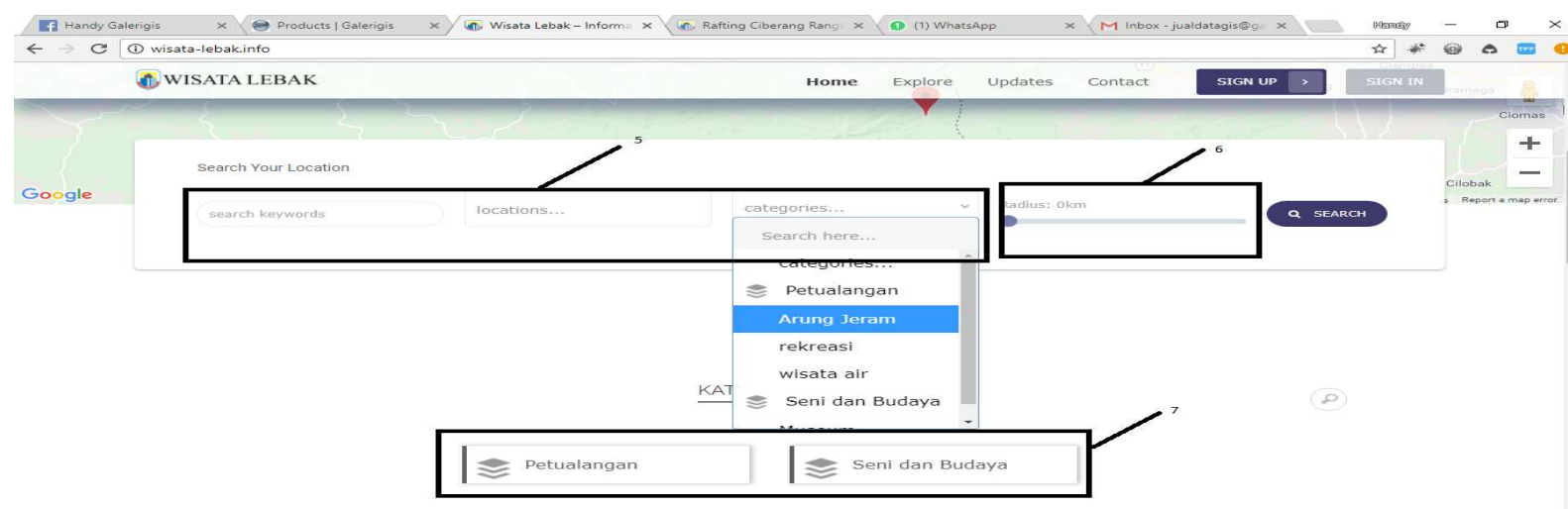

Gambar 5. Bagian search keyword dan radius

Keterangan:

5. Search your location. Ini adalah hasil dari pencarian akan di tampilkan di dalam maps. ambil contoh Museum Multatuli. Masukkan Search Keyowrdnya “museum” dan ketikkan location "Lebak Banten", kategori nya di kosongkan saja, kemudian klik search. Di bawah ini adalah contoh hasilnya. 


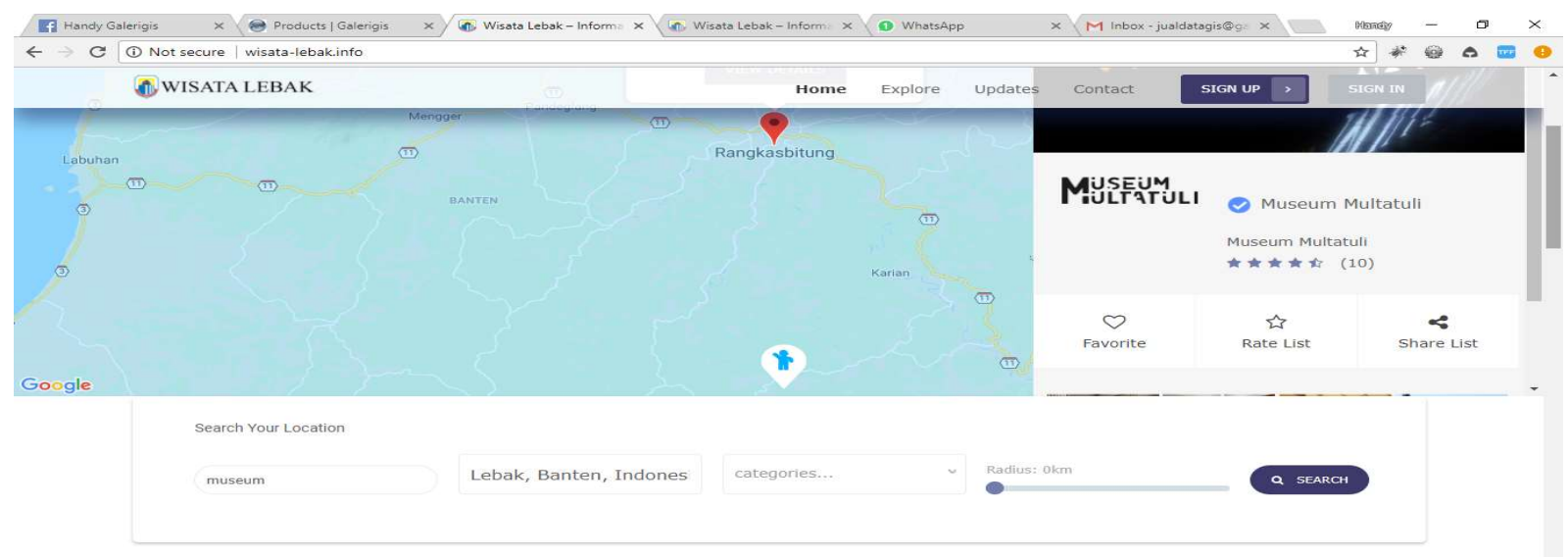

$\#$

Gambar 6. Hasil search dari search your location

6. Radius Search adalah hasil pencarian optional. Berfungsi apabila untuk mencari tempat wisata terdekat dengan lokasi sekarang. Satuan dalam kilometer.

7. List Kategori. Hasil Sortir Kategori yang telah di masukkan. Ada dua kategori dalam website ini,yaitu Petualangan dan seni dan budaya. Dari masing-masing kategori terdapat sub kategori.

\section{Bagian III}

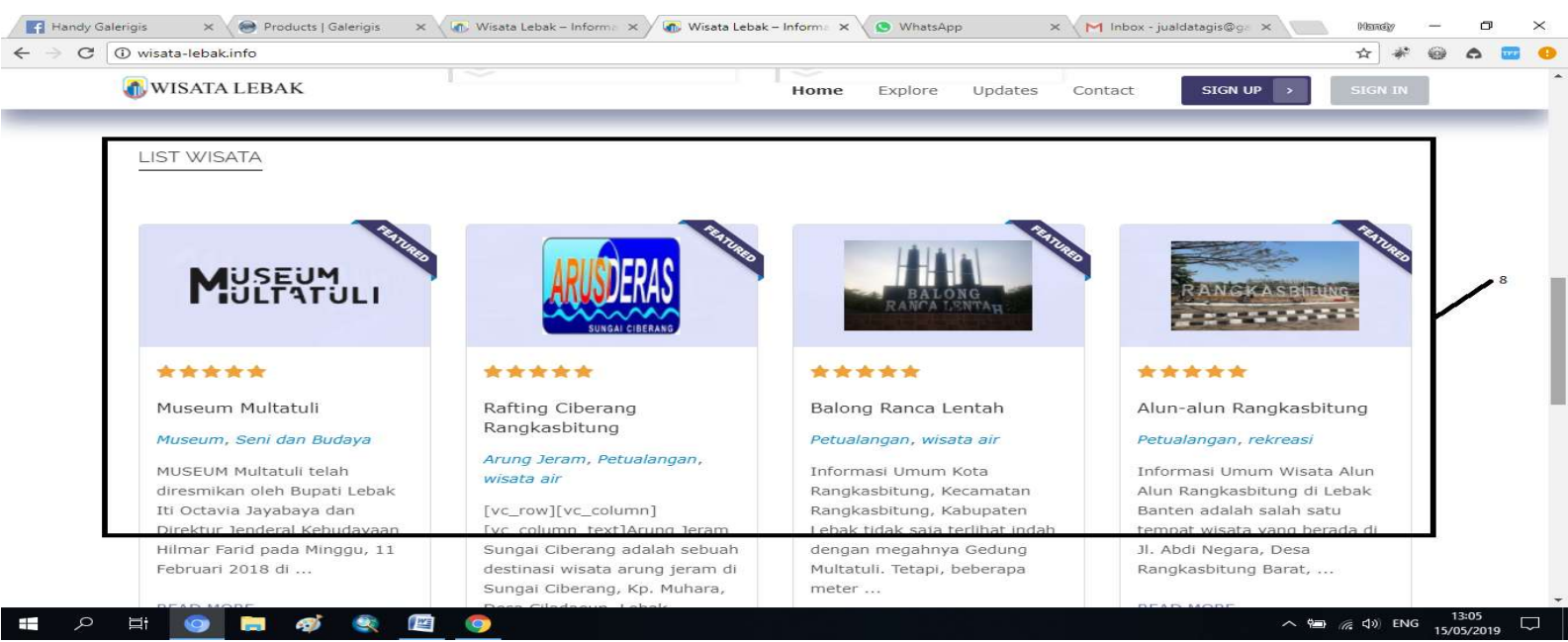

Gambar 7. List tempat wisata yang sudah di input.

\section{Keterangan:}

8. Berisikan 4 list wisata yang sudah di input. Menampilkan dalam bentuk slideshow. 


\section{Bagian IV}

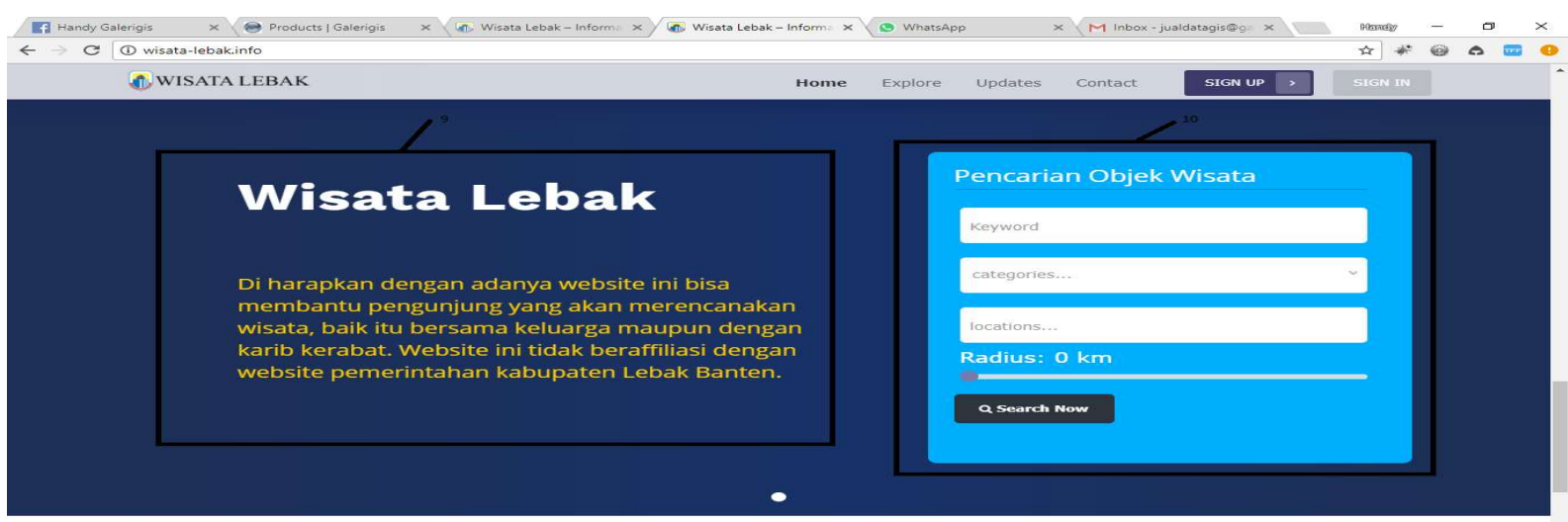

Gambar 8. Deskripsi Website dan Search Keterangan:

9. Deskripsi. Berisikan informasi secara umum isi website

10. Search. Sama dengan search pada map namun perbedaannya terdapat pada outputnya. Adapun output search ini adalah berupa list wisata sesuai kata kunci.

\subsection{Backend}

Pada bagian ini hanya dibatasi pada proses input tempat wisata kemudian mengedit serta menghapus informasi. Untuk control secara penuh akan disajikan dalam dokumentasi "system admin" di mana dokumentasi terpisah dari dokumentasi end user. Silahkan sign in terlebih dahulu dengan menggunakan username dan password yang telah di berikan. Di bawah ini adalah tampilan awal bagian backend dari website ini. Setelah sign in anda akan di arahkan ke link http://wisata-lebak.info/signup/?action=login. Setelah berhasil login maka akan keluar tampilan dashboard seperti gambar di bawah ini.

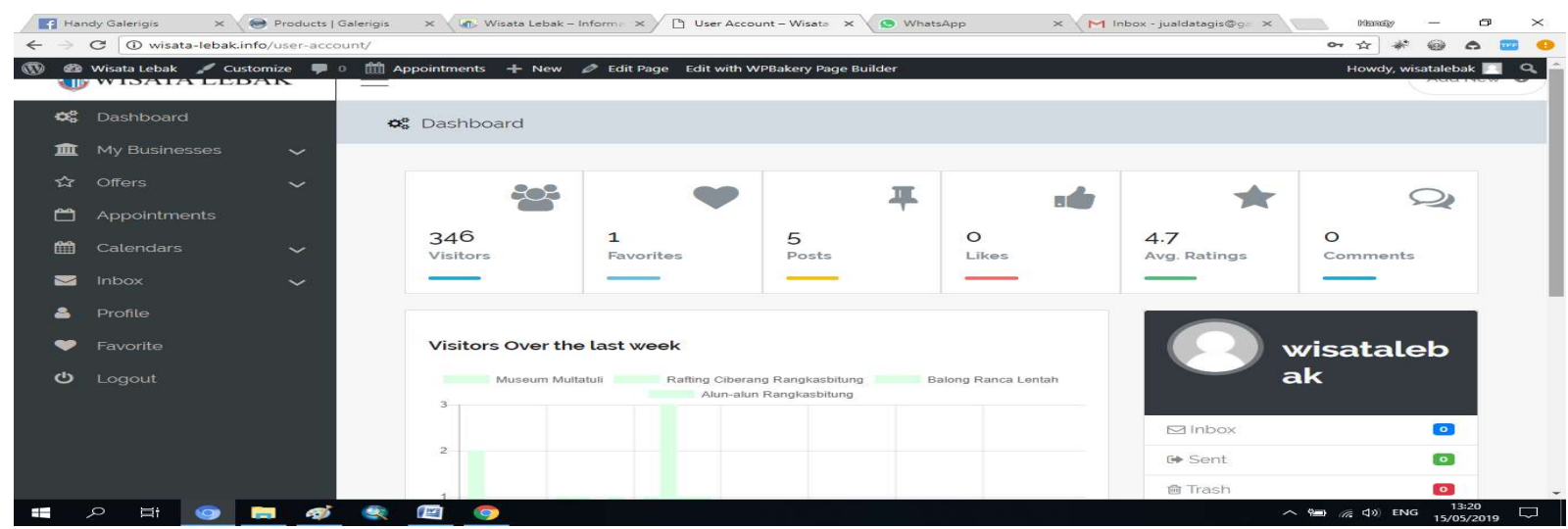

Gambar 9.Tampilan dashboard.

Di sini dapat melihat list bisnis yang dipunyai (add,edit dan delete), kemudian juga menambahkan offer (informasi tambahan). Pertama kita ke bagian my business dulu. Ada di My business->all, maka akan keluar tampilan seperti gambar di bawah ini. 


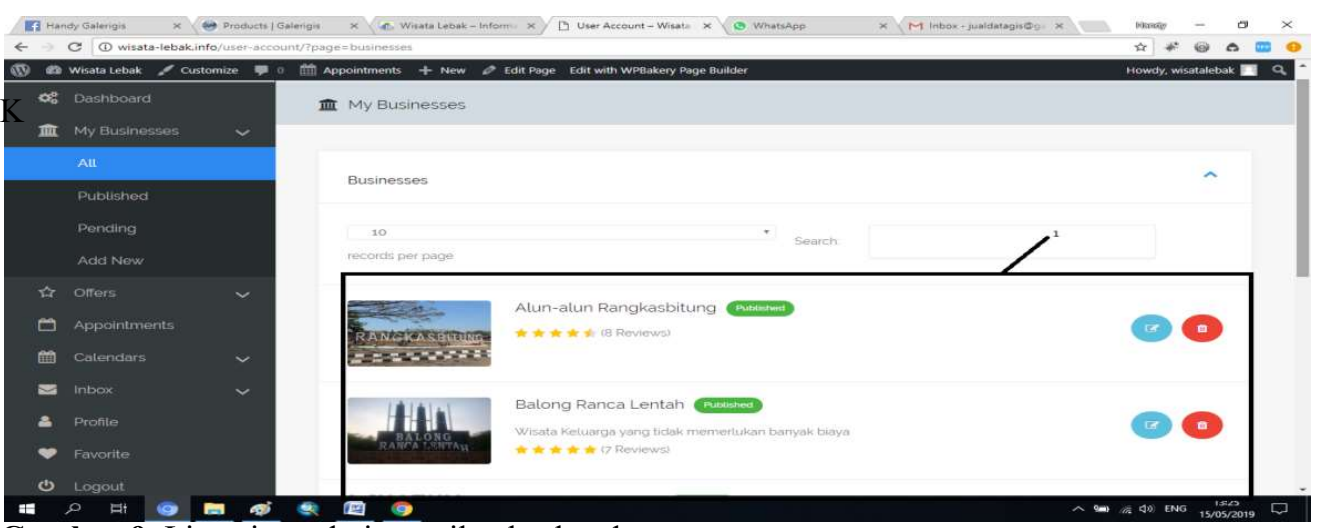

Gambar 9. List wisata dari tampilan backend

Keterangan:

Ini merupakan list wisata yang sudah dinput. Karena ada 4 wisata yang sudah di input,maka keseluruhan listnya akan terlihat di sini. Sekarang silahkan klik tombol "edit" salah satu list wisata yang ada,maka akan keluar gambar seperti di bawah ini.

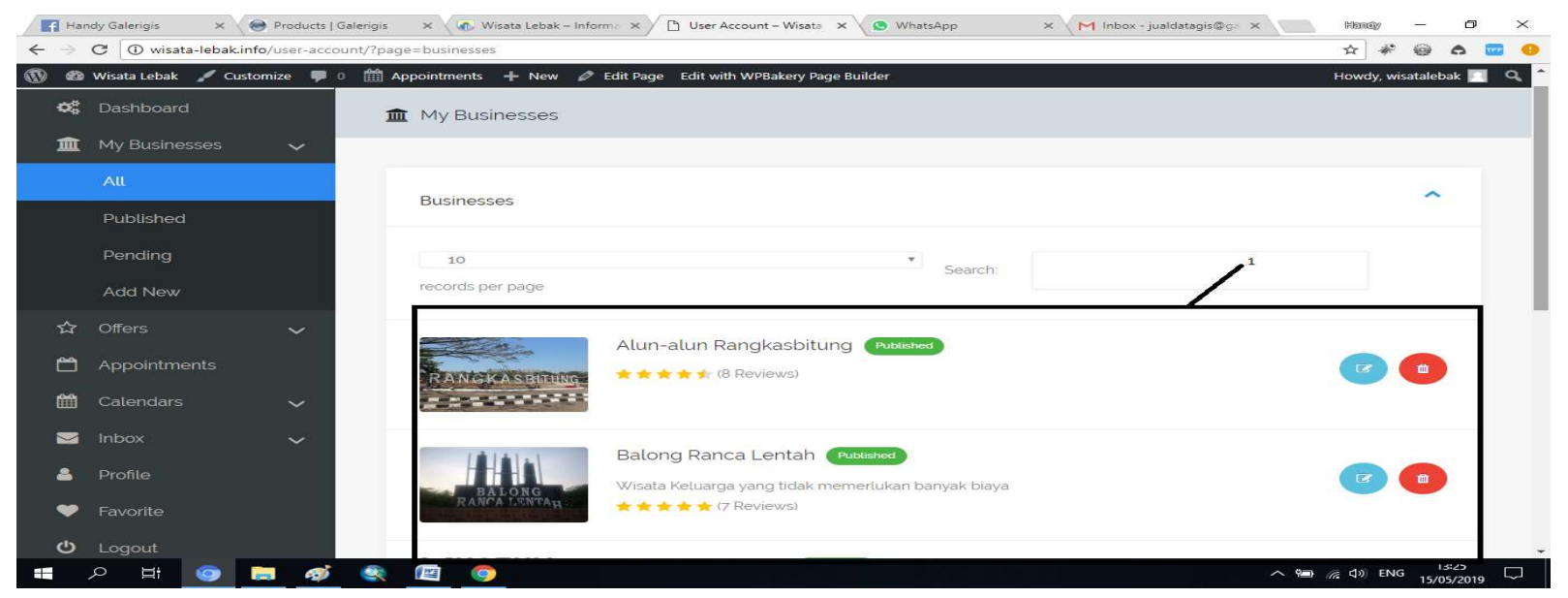

Gambar 10. Manage business menu

Dari gambar 10. terdapat dua tombol, "edit" untuk melakukan editing terhadap list wisata yang telah di input dan "delete" untuk menghapus data dari list. Selanjutnya klik "edit", untuk melihat isinya. Selain itu juga berisikan listlist menu yang telah kita input, silahkan lakukan editing sesuai dengan kebutuhan. Untuk keterangan menu akan dijelaskan setelah ini.

Selanjutnya ke bagian "New" dari menu "Manage Businesses". Setelah di klik akan keluar menu-menu yang perlu input.

[1.] Name. Ini adalah nama tempat wisata

[2.] Logo. Silahkan masukkan gambar logo dari tempat wisata yang di maksud

[3.] Description. Ini adalah deskripsi singkat dari tempat wisata yang akan di masukkan. Untuk website ini saya buat seragam semua jadi "Berisikan informasi tentang tempat wisata

[4.] About. Berisikan Profil dari tempat wisata

[5.] Slogan (optional). Berisikan motto dari tempat wisata yang akan di input

[6.] Categories. Kategori yang sudah di setting oleh "system admin". Untuk website ini Cuma satu yaitu "tempat wisata"

[7.] Category Icon. Silahkan pilih icon yang sudah di sediakan

[8.] Klik Next 
[9.] Opening hours. Silahkan masukkan jam kerja (optional), dapat di kosongkan

[10.] Building. Nama Gedung dari tempat wisata

[11.] Street. Alamat Lengkap tempat wisata

[12.] City. Nama Kota/Kabupaten

[13.] Location. Silahkan pilih salah satu Provinsi yang sudah di list

[14.] Masukkan alamat yang sudah terdaftar dari google address, misalkan: alun-alun Rangkasbitung. Silahkan pilih alamat yang cocok dengan keadaan lapangan. Note: terkadang alamat dari google maps tidak benar jadi perlu lakukan verifikasi ulang.

[15.] Phone 1. Inputkan No Handphone/Telp

[16.] Phone 2. Inputkan No Handphone/Telp tambahan

[17.] Email 1. Inputkan alamat e-mail

[18.] Email 2. Inputkan alamat e-mail tambahan

[19.] Website. Masukkan nama website tempat wisata yang akan di input

[20.] Facebook. Masukkan fans page facebook tempat wisata (optional)

[21.] Twitter. Masukkan official twitter tempat wisata (optional)

[22.] Google Plus. Masukkan alamat google plus jika ada (optional)

[23.] Linkedin. Masukkan alamat link linkedin jika ada (optional)

[24.] Youtube. Masukkan youtube channel tempat wisata (optional)

[25.] Instagram. Masukkan intagram official jika ada (optional)

[26.] Pinterest. Masukkan alamat pinterest jika ada (optional)

[27.] Klik Next

[28.] Post Comment. Klik On jika Wall anda boleh di berikan komentar

[29.] Tags. Masukkan tag

[30.] Masukkan list tempat wisata sudah di siapkan

[31.] Range Radius. Masukkan jangkauan luas Masukkan angka 100 aja kalau tidak tahu. Satuan dalam kilometer

[32.] Silahkan cek ulang hasil inputan kemudian klik "new"

Untuk saat ini pembuatan web wisata kabupaten Lebak hanya berisi 4 destinasi yang ada yaitu Musium Multatuli, Alun-alun Rangkasbitung, Ranca Lentah dan Rafting Ciberang. Untuk berikutnya akan ditambah dengan obyek wisata yang lain yang ada di kabupaten Lebak yang sudah banyak, karena web nya sudah ada selanjutnya menambahkan saja.

Hal ini diharapkan menjadi masukan bagi masyarakat yang ada di Kabupaten Lebak khususnya dan di luar wilayah Kabupaten Lebak pada umumnya, karena berdasarkan wawancara dengan beberapa responden yang ada di wilayah Ragkasbitung, ketika di perlihatkan web yang sudah ada yaitu :http://wisata-lebak.info maka menurut mereka hal itu dapat membantu untuk melihat destinati apa saja yang ada di kabupaten lebak tersebut.

\section{KESIMPULAN}

Berdasarkan hasil pembahasan hingga perancangan dan pembangunan sistem informasi geografis tersebut maka dapat diambil beberapa kesimpulan sebagai berikut :

1. Sistem Informasi Geografis dapat digunakan sebagai sistem untuk dapat mencari dan melihat lokasi obyek wisata yang ada di kabupaten Lebak yang berada di Rangkasbitung maupun wilayah yang masuk di Kabupaten Lebak dan sekitarrnya sesuai dengan yang diinginkan dimanapun dan kapanpun.

2. Dengan demikian diharapkan masyarakat yang akan berwisata pada daerah kabupaten Lebak akan terpandu baik dari segi lokasi maupun informasi-informasi yang diperlukan. Sehingga dapat memilih mana obyek wisata memang sesuai dengan anggaran yang disediakan, jenis obyek wisata apa yang lengkap sesuai dengan yang diinginkan, mengingat bahwa obyek wisata yang ada di kabupaten Lebak ini sangat banyak. 


\section{DAFTAR PUSTAKA}

[1.] Budianto, Eko. 2010. Sistem Informasi Geografis dengan Arc View GIS.Yogyakarta: Andi Offset.

[2.] Hanafi, Muhammad. 2011. SIG dan AHP untuk Sistem Pendukung Keputusan Perecanaan Wilayah Industri dan Pemukiman Kota Medan. Skripsi Program Studi Ilmu Komputer. Medan, Indonesia: Universitas Sumatera Utara.

[3.] Helmi Kurniawan, Muhammad Rusdi Tanjung, 2017, Sistem Informasi Geografis Objek Wisata Alam diProvinsi Sumatera Utara Berbasis Mobile Android, Jurnal Ilmiah SISFOTENIKA, Vol. 7, No. 1, Januari 2017

[4.] I Gede Riana, Ni Luh Putu Wiagustini 2014, Master Plan UMKM Berbasis Perikanan untuk Meningkatkan Pengolahan Produk Ikan yang Memiliki Nilai Tambah Tinggi, JURNAL EKONOMI KUANTITATIF TERAPANVol 7, 2014

[5.] Mezyad Alterkawi, 2001, Application of GIS in Transportation Planning: The Case of Riyadh, the Kingdom of Saudi Arabia, GBER Vol. 1 No. 22001 pp 38-46

[6.] Moh Muthohir, Ahmad Zainudin, 2016, Implementasi GIS untuk Pemetaan Lokasi dan Promosi Produk Kreatif UMKM di Kabupaten Kendal, Seminar Nasional Ilmu Komputer (SNIK 2016) - Semarang, 10 Oktober 2016, ISBN: 978-602-1034-40-8

[7.] Mohammad A. Rob, 2003, Applications of Geographical Information Systems in Understanding Spatial Distribution of Asthma, Informing Science Journal Volume 6, 2003

[8.] Pahlevy, Randy, Tesar. 2010. Rancang Bangun Sistem pendukung Keputusan Menentukan penerima Beasiswa dengan Menggunakan metode SimpelePrahasta, Eddy. 2006. Sistem Informasi Geografis (Membangun Web Based GIS dengan Mapserver). Bandung : CV. Informatika.

[9.] Riwayatiningsih, Hartuti Purnaweni, 2017, Pemanfaatan Sistem Informasi Geografi dalam Pengembangan Pariwisata Geographic Information System Utilization in Tourism Development, Proceeding Biology Education Conference Volume 14, Nomor 1

[10.] Verka JOVANOVIĆ, Angelina NJEGUŠ, 2008. The Application Of Gis And Its Components In Tourism, Yugoslav Journal of Operations Research, Vol 18 (2008), Number 2, 261-272 
JURNAL INFORMATIK Edisi ke-15, Nomor 3, Desember 2019

ISSN : 2655-139X (ONLINE)

ISSN : 0216-4221 (PRINT) 